\title{
REAL OPTIONS APPROACH: A BANK ACQUISITION BY BANK $X$
}

\author{
Shantie Poespa Dewi ${ }^{1}$ \\ BINUS Business School \\ Junius Tirok $^{2}$ \\ BINUS Business School
}

\begin{abstract}
Indonesia offers a lot of promising growth opportunities and particularly to the banking industry, a combination of attractive macro-economic conditions and introduction of new regulatory policies as well as reformation to consolidate and strengthen the banking sector primarily by M\&A activity provides an attractive backdrop for acquisition of Indonesian banks by foreign investors. In this paper, we introduce real options theory as an alternative to a traditional project valuation for a bank acquisition that would allow the acquiring firm to recognize the options embedded in their investments.

The objective of this case study is to analyze, from real options perspective, whether the acquisitions of the target firm compliment the acquiring firm. The methods use for the analysis are DCF, Black-Scholes and Binomial Lattice that would help determine the project real value, which result suggested that the acquiring firm should reconsider their options.

On this thesis, the DCF method suggesting that the acquisition of Bank Y by Bank $\mathrm{X}$ does increase the value of Bank $\mathrm{X}$ but there would not be added value on the synergy itself. While from the real options perspective, the project value (with and without real options flexibility) is worth less than the target firm underlying assets and has doubtful prospect.
\end{abstract}

\footnotetext{
${ }^{1,2}$ Shantie Poespa Dewi is an alumni of BINUS Business School (daffy_z@yahoo.com) and Junius Tirok is a faculty of BINUS Business School (jtirok@binus.edu).
} 
Keywords: mergers and acquisitions, real options, black-scholes model, binomial

\section{INTRODUCTION}

During the last twenty years, mergers and acquisitions (M\&A), both domestic and international, have become the front line strategic option for organizations attempting to have competitive advantage over its competitors. This is due to increasing competition, new financing possibilities and changes in regulation all over the world. However, despite the popularity, the general consensus is that about $80 \%$ of M\&A do not reach to their financial goals (Nahavandi and Malekzadeh 1993) and about 50\% simply fail (Cartwright and Cooper 1995; Child et al. 2001; Sally Riad, 2007). The reasons for such failures are vary from incompatible and unsuccessful organizational marriage, the inability to integrate the operation well as well as rushing the decision to acquire another firm without fully understanding the options they have.

Group Bank X ("the Group") is a foreign bank with a worldwide network and has appetite for acquisition in Indonesia is mainly to develop an expanded retail and SME banking enterprise with high organic growth potential in profitable markets. To ensure that objective achieved, recognizing real options can help decision makers assess the profitability of new projects and understand whether and when to proceed with the later phases of projects that have already been initiated. The ability to alter decisions in response to new information may contribute significantly to the value of a project. Many believe that by ignoring real options, many companies are undervaluing genuine opportunities for investment and for growth

\section{PROBLEM STATEMENT}

To analysis whether the acqusition of Bank $\mathrm{Y}$ by Bank X provides the flexibility that compliment Bank $\mathrm{X}$ existing business and accelerates the organic growth strategy being pursued. Also, whether Bank X have 
embedded options - the right but not the obligation to take some action in the future - prior to the acquisition of Bank Y.

\section{THEORITICAL FRAMEWORK}

The terms of merger and acquisition are often uttered in the same breath and used as though they were synonymous, however, it mean slightly different things. On a narrower perspective, a merger is when two firms combined as one to achieve common goals with the two firms' shareholder remain as joint owners (Sherman, 2005) while an acquisition is the buying of one firm (the 'target') by another in which it could be friendly or hostile.

According to Schwartz and Trigeorgis (2001), by doing an acquisition, a firm that seek a quick enter into a new market niche may find it cheaper or more convenient option rather than develop it on its own. The value of a firm's growth options may be enhanced through acquisitions by decreasing the exercise price, increasing the present value of future profits earned upon exercise, and allowing for greater flexibility in timing the exercise of the options.

Another option that could be achieved through acquisitions is synergy gains. In M\&A, definition of synergy is when the value of the transaction exceeds the value of two different firms combine together. In relation to financial synergy, according to Ross, Westerfield, Jaffe (2002), the classification of incremental cash flows as the possible sources fall into four basic categories consist of revenue enhancement, cost reduction, tax gains and the cost of capital (= discount rate).

Real options analysis extends financial option theory to options on real or nonfinancial assets. Thus, similar to a financial option that gives its owner the right — but not the obligation — to purchase or sell a security at a given price, Trigeorgis (1996) sees real options as investments in real asset which confer a firm the right but not the obligation to make a potentially value-accretive investment in the future, as opposed to the financial asset. 
According to real options theory, a project could be promising when NPV $>0$ and NPVq $>1$, however, when NPVq $>1$ but NPV $<0$ the project should not to be proceed (refer to below graph).

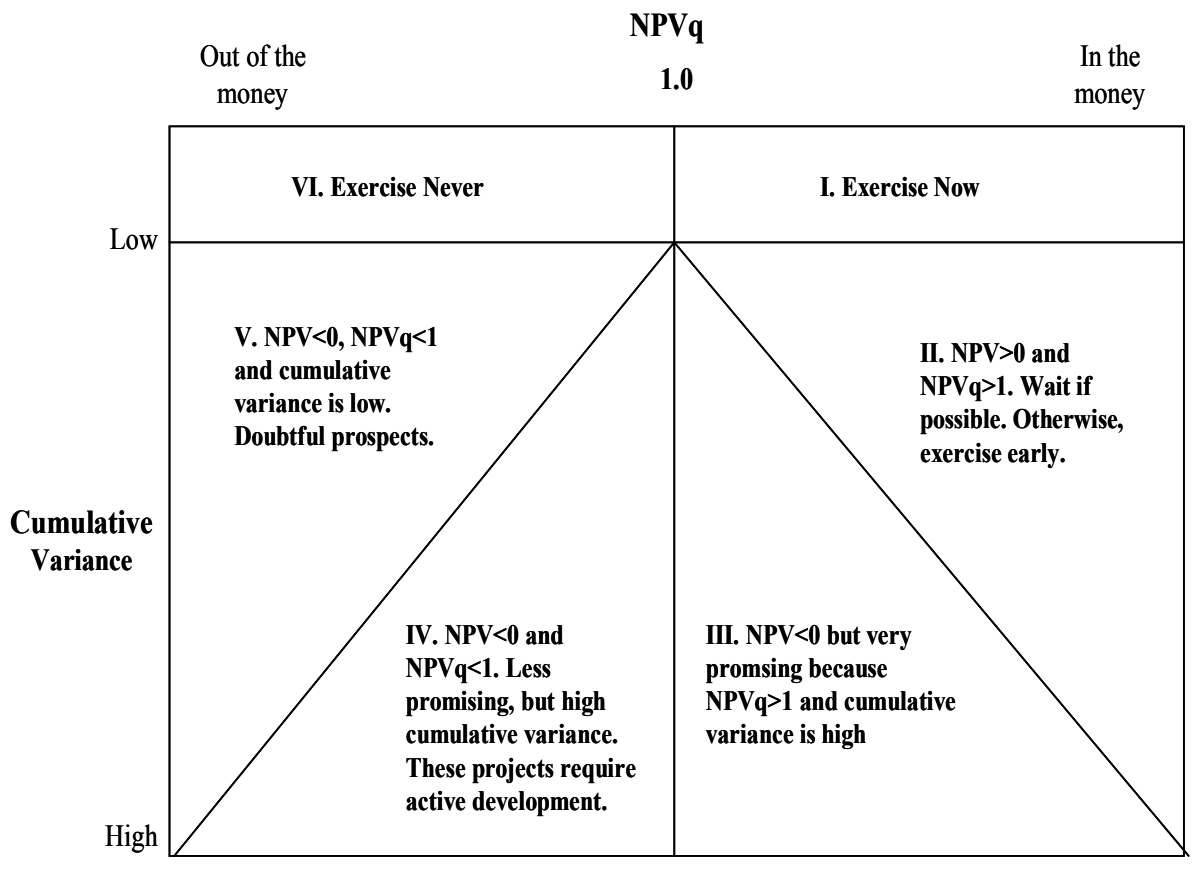

Source: Harvard Business School

Graphic 1. NPV

Real options approach is best viewed as a complement to standard discounted cash flow (DCF). By adding an important dimension of analytical flexibility, real options allow for a better melding of strategic intuition and analytical inflexibility.

In relation to management decision to invest or not invest in a project, Shapiro (2006) concludes there is several elements of value in relation to its discretion. The first element is when the length of time a project can be deferred in which the ability to defer a project gives a firm more time to examine the course of future events and to avoid costly errors if unfavorable development occurs. The second element is risk of the 
project, in which, the riskier the investment the more valuable is an option on it. The third one is the level of interest rate since high interest rates generally raise the value of projects that contain growth options. Last to consider is the proprietary nature of the options since an exclusively owned option is clearly more valuable than one that is shared with others.

\section{METHODOLOGY}

There are four widely used methods for valuing target firms, which is market multiple analysis, the corporate valuation model that estimates a firm's operating value as the net present value (NPV) of projected cash flows also called discounted cash flow (DCF), free cash flow to equity (FCFE) model and adjusted present value model which ideally suited for situation with changing capital structure. On this thesis, the method used to valuing target firms is discounted cash flow (DCF). Its approach in an M\&A setting attempts to determine the value of the firm by computing the present value of cash flows over the life of the company.

The expression for free cash flow is:

Free Cash Flow $=$ EBIT $(1-\mathrm{T})+$ Depreciation - CAPEX - DNWC

where:

- EBIT is earnings before interest and taxes.

- $\mathrm{T}$ is the marginal cash (not average) tax rate, which should be inclusive of federal, state and local, and foreign jurisdictional taxes.

- Depreciation is noncash operating charges including depreciation, depletion, and amortization recognized for tax purposes. CAPEX is capital expenditures for fixed assets.

- DNWC is the change in net working capital.

The value of the firm derived from free cash flows arising after the forecast period is captured by a terminal value. Terminal value is estimated in the last year of the forecast period and capitalizes the present value of all future cash flows beyond the forecast period. The terminal region cash flows are projected under a steady state assumption that the 
firm enjoys no opportunities for abnormal growth or that expected returns equal required returns in this interval.

A standard estimator of the terminal value in period $t$ is the constant growth valuation formula:

$$
\text { Terminal Value }{ }_{t}=\frac{\mathrm{FCF}_{\mathrm{t}}(1+\mathrm{g})}{(\mathrm{WACC}-\mathrm{g})}
$$

where:

- FCF is the expected free cash flow to all providers of capital in period $t$.

- WACC is the weighted average cost of capital.

- $\mathrm{g}$ is the expected constant growth rate in perpetuity per period.

Once a schedule of free cash flows is developed for the enterprise, the Weighted Average Cost of Capital (WACC) is used to discount them to determine the present value, which equals the estimate of firm or enterprise value.

To find real options value, the approach is by applying an option pricing model. The two most common are the Black-Scholes-Merton model and the Cox-Ross-Rubenstein Binomial-Lattice model. Both models were created primarily for the purpose of valuing market-traded options, in which in this thesis will be used to valuing project flexibility worth.

The link between investments and Black-scholes inputs can be seen
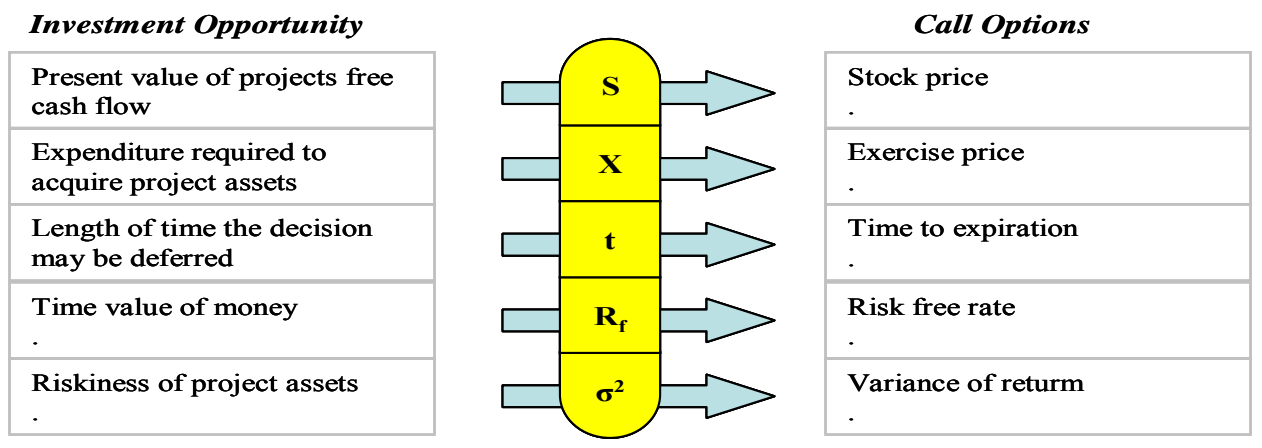

Source: Timothy Luehman, Investment Opportunities as Real Options, Harvard Business Review, July-August 1998

Figure 1. Black-scholes Inputs 
The Black-Scholes formula valuation of call or put option as follows:

Value of Call $=S \mathrm{e}^{(\mathrm{b}-\mathrm{r}) \mathrm{T}} \mathrm{N}\left(\mathrm{d}_{1}\right)-X \mathrm{e}^{-\mathrm{rT}} \mathrm{N}\left(\mathrm{d}_{2}\right)$

Value of Put $=-S e^{(b-r) T} N\left(-d_{1}\right)+X e^{-r T} N\left(-d_{2}\right)$ where:

- b is the "cost of carry," defined as risk-free rate minus the dividend yield (q).

- $\mathrm{d}_{1}=\frac{\ln (\mathrm{S} / \mathrm{X})+\left(\mathrm{b}+\mathrm{\sigma}^{2} / 2\right) \mathrm{T}}{? \mathrm{~T}}$

- $\mathrm{d}_{2}=\mathrm{d}_{1}-\sqrt{\mathrm{T}}$

Before Fisher Black and Myron Scholes came along in 1973, economists had tried for years to develop satisfactory models to price options, in which, the widely known Black-Scholes model is a narrow case of the binomial model. The Binomial options pricing model approach is widely used as it is able to handle a variety of conditions for which other models cannot easily be applied. The binomial pricing model uses a "discrete-time framework" to trace the evolution of the option's key underlying variable via a binomial lattice (tree), for a given number of time steps between valuation date and option expiration.

\section{RESULT}

The DCF method suggesting that the expected synergy value achieved from the acquisition of Bank Y would be 5.63 times higher than Bank X expected value.

Moreover, with the acquisition, Bank X value would increase by 3.78 times.

On real option valuation, Black-Scholes method demonstrate that this acquisition project have a doubtful prospects although the project worth is a positive IDR 7,08 billion. 
Table 1. Valuation of Firm with Synergy

\begin{tabular}{|c|c|c|c|c|c|c|c|}
\hline \multicolumn{8}{|c|}{ Valuation of Firm with Synergy } \\
\hline Financial Data & Year 0 & Year 1 & Year 2 & Year 3 & Year 4 & Year 5 & $\begin{array}{c}\text { Terminal } \\
\text { Year }\end{array}$ \\
\hline Year & & 1 & 2 & 3 & 4 & 5 & \\
\hline Expected growth rate & & $0.00 \%$ & $14.10 \%$ & $14.10 \%$ & $14.10 \%$ & $14.10 \%$ & $0.00 \%$ \\
\hline Reinvestment rate & & $0.00 \%$ & $0.00 \%$ & $0.00 \%$ & $0.00 \%$ & $0.00 \%$ & $0.00 \%$ \\
\hline Operating Income (EBIT) & 19.29 & 19.29 & 22.01 & 25.11 & 28.65 & 32.69 & 32.69 \\
\hline Tax rate & & $30.00 \%$ & $30.00 \%$ & $30.00 \%$ & $30.00 \%$ & $30.00 \%$ & $30.00 \%$ \\
\hline $\mathrm{EBIT} *$ tax rate & & 5.79 & 6.60 & 7.53 & 8.59 & 9.81 & 9.81 \\
\hline EBIT (1-tax rate) & & 13.50 & 15.40 & 17.58 & 20.05 & 22.88 & 22.88 \\
\hline Reinvestment & & 0.00 & 0.00 & 0.00 & 0.00 & 0.00 & 0.00 \\
\hline FCFF & & 13.50 & 15.40 & 17.58 & 20.05 & 22.88 & 22.88 \\
\hline Cost of capital & & $6.59 \%$ & $6.59 \%$ & $6.59 \%$ & $6.59 \%$ & $6.59 \%$ & $6.59 \%$ \\
\hline Terminal value & & & & & & 347.07 & \\
\hline PV of FCFF & & 12.67 & 13.56 & 14.51 & 15.53 & 268.85 & \\
\hline Value of firm today & 325.12 & & & & & & \\
\hline
\end{tabular}

Table 2. Option / Project Worth

\begin{tabular}{|lcc|r|}
\hline \multicolumn{1}{|c|}{ Description } & Assumptions & (in IDR billion) \\
\hline Strike Price (Investment) & $\mathrm{x}$ & 2x Target firm's value $(2006)$ & 321,71 \\
Underlying asset $(\mathrm{PV})$ & $\mathrm{s}$ & Value of firm $(2006)$ & 160,85 \\
Variance & $\sigma^{2}$ & Bank X historical & $12,05 \%$ \\
\hline Risk free rate $(\mathrm{r})$ & $\mathrm{r}$ & $\mathrm{SB}$ I rate & $9,75 \%$ \\
\hline Time to expiration & $\mathrm{t}$ & Next acquisition & 5 \\
& & & $-160,9$ \\
NPV & & $\mathrm{s}-\mathrm{x}$ & 0,80 \\
NPVq & $\mathrm{s} /(\mathrm{x} / 1+\mathrm{r})^{\mathrm{t}}$ & 0,27 \\
\hline Cumulative variance & $? \mathrm{t}^{*} \sigma^{2}$ & $4,40 \%$ \\
Table & & $\mathbf{7 , 0 8}$ \\
Option/Project worth & & & \\
\hline
\end{tabular}

To support the result of Black-Scholes method, a scenario summary is produce to understand the project value in the best and worse case condition. 
Table 3. Scenario Summary

\begin{tabular}{lrrrr}
\hline Scenario Summary & & & & \\
& Current Values: & Best case & Expectedcase & Worst case \\
\hline Changing Cells: & & & & \\
\hline Strike Price (Investmen & 321,71 & 160,85 & 321,71 & 402,13 \\
Undertying asset (PV) & 160,85 & 160,85 & 160,85 & 150,24 \\
Variance & $12,05 \%$ & $39,10 \%$ & $12,10 \%$ & $3,00 \%$ \\
Risk free rate (r) & $9,75 \%$ & $7,40 \%$ & $9,80 \%$ & $12,80 \%$ \\
Time to expiration & 5 & 10 & 5 & 5 \\
\hline Result Cells: & & & & $-251,9$ \\
\hline NPV & $-160,9$ & 0,0 & $-160,9$ & 0,68 \\
NPVq & 0,80 & 2,04 & 0,80 & 0,07 \\
Cumulative Variance & 0,27 & 0,87 & 0,27 & 6,61 \\
\hline Project Worth & 7,08 & 7,08 & 7,08 & \\
\hline
\end{tabular}

Notes: Current Values column represents values of changing cells at time Scenario Summary Report was created. Changing cells for each scenario are highlighted in gray.

The scenario summary suggested that only when the best scenario takes place - where the investment cost is equal to the target firm expected value combined with expanded project timeline to 10 years and higher volatilitythe project could be exercised. The result is complimenting the BlackScholes valuation which suggesting that the acquisition of Bank $\mathrm{Y}$ is doubtfully will bring an added value to the Bank.

Considering above result, abandonment options (one of the option available in real options) should be considered. Thus, to see the availability of this specific option in Bank Y acquisition project, binomial lattice method is used to evaluate it since in finance, the binomial option model provides a generalisable numerical method for the valuation of options.

The binomial lattice method result suggesting that there would be no abandon option embedded in the acquisition project of Bank Y, considering the negative result on the real option value (NPV with real options flexibility). 
Table 4. NPV with real options flexibility

Abandonment Options (in IDR billion)

$\begin{array}{lr}\text { PV of underlying assets } & 160,85 \\ \text { Investment Expenditure } & 321,7 \\ \text { Time to option expiration } & \\ \text { Volatility } & 12,1 \% \\ \text { Risk free rate } & 9,8 \% \\ & \\ \mathrm{r}^{*} & 0,082658 \\ \mathrm{u} & 1,12806 \\ \mathrm{~d} & 0,886477 \\ \mathrm{p} & 0,812063 \\ \text { 1-p } & 0,187937 \\ \text { Binomial value } & 1,01837\end{array}$

$\begin{array}{rlcr}160,85 & \text { er*t } & 2 \\ 321,71 & \text { e-r*t } \quad 1 & \\ 5 & \text { American (1)/European }(0) & 1 \\ 12,1 \% & \text { Call (1)/Put (0) } & 0 \\ 9,8 \% & & \end{array}$

\begin{tabular}{|c|c|c|c|c|c|c|c|}
\hline & & & & \multirow{2}{*}{181,45} \\
\hline & & & 181,45 & & 181,45 & & \\
\hline \multirow[t]{13}{*}{ STEP 1} & & & 140,25 & & 140,25 & & 140,25 \\
\hline & Price & 160,85 & & 160,85 & & 160,85 & \\
\hline & Call & 160,85 & & 160,85 & & 160,85 & \\
\hline & & & 142,59 & & 142,59 & & 142,59 \\
\hline & & & 179,11 & & 179,11 & & 179,11 \\
\hline & & & & 126,41 & & 126,41 & \\
\hline & & & & 195,30 & & 195,30 & \\
\hline & & & & & 112,06 & & 112,06 \\
\hline & & & & & 209,65 & & 209,65 \\
\hline & & & & & & 99,33 & \\
\hline & & & & & & 222,37 & \\
\hline & & & & & & & 88,06 \\
\hline & & & & & & & 233,65 \\
\hline \multicolumn{8}{|l|}{ STEP 2} \\
\hline & & & & & & & $293,83 \mathbf{A}$ \\
\hline \multirow[t]{4}{*}{ Risk free rate - Assumptions } & & Up & $12,8 \%$ & & & & Continue \\
\hline & $9,8 \%$ & & & & & 260,60 & \\
\hline & & Down & $7,4 \%$ & & & Open & \\
\hline & & & & & 208,87 & 235,50 & 230,90 \\
\hline Salvage value & & 160,85 & & & Open & Open & Contnue \\
\hline \multirow[t]{15}{*}{ Continuing } & & 293,83 & & $168,53 \mathrm{C}$ & 190,02 & 210,39 & \\
\hline & & & & Open & Open & Open & \\
\hline & & & 138,03 & 155,62 & 171,17 & 187,86 & 181,45 \\
\hline & & & Abandon & Abandon & Open & Open & Continue \\
\hline & & 120,77 & 132,55 & 142,72 & 156,63 & 165,33 & \\
\hline & & Abandon & Abandon & Abandon & Abandon & Open & \\
\hline & & & 127,07 & 136,52 & 142,09 & 155,95 & 160,85 B \\
\hline & & & Abandon & Abandon & Abandon & Abandon & Abandon \\
\hline & & & & 130,31 & 140,00 & 146,56 & \\
\hline & & & & Abandon & Abandon & Abandon & \\
\hline & & & & & 137,90 & 148,15 & 160,85 \\
\hline & & & & & Abandon & Abandon & Abandon \\
\hline & & & & & & 149,73 & \\
\hline & & & & & & Abandon & \\
\hline & & & & & & & 160,85 \\
\hline Real Option Value & & $-40,08$ & & & & & Abandon \\
\hline Continuing & & 293,83 & & & & & \\
\hline
\end{tabular}




\section{CONCLUSION}

The standard DCF model is sufficient for valuing most traditional businesses, but it lacks the flexibility to value many new economy companies. Real options theory, a complement to DCF, adds that necessary flexibility. In the process, real options theory addresses important strategic and financial issues.

In this acquisition project, a positive DCF analysis result is not complemented with a positive result in real options analysis since DCF suggesting that there would be added value in the acquisition while from the real options perspective, the project has a doubtful prospect. Not to mention, should the acquirer wish to divest the target bank post acquisition, it would be a shortfall since the project NPV with real options flexibility is less than the Firm's value. Thus, whenever possible, it would be wise for Bank X to search for another bank to be acquired.

In spite of the valuation result, the acquisition of Bank $\mathrm{Y}$ does significantly enhance Bank $\mathrm{X}$ banking performance.

\section{REFERENCES}

Eugene F. Brigham, Michael C. Ehrhardt. (2005). Financial Management, Theory and Practice. South-Western College Pub.

Friedrich Trautwein. (1990). Merger Motives and Prescription. Strategic Management Journal.

Jack W. Trifts. (1991). Corporate Takeover Bids, Methods of Payment, and the Effects of Leverage. Quarterly Journal of Business and Economics.

Gerald I. White, Ashwinpaul C.Sandhi, Dov Fried. (2005). Financial Management 'Theory and Practice'. Wiley

Jonathan Mun. (2006). Real Options Analysis 'Tools and Techniques for Valuing Strategic Investments and Decisions ( $2^{\text {nd }}$ ed.). Wiley 
Jonathan William \& Angel Liao. (2008). The Search for Value: Crossborder Bank M\&A in Emerging Markets. Comparative Economic Studies.

Maurizio Zollo \& Harbir Singh. (2004). Deliberate Learning in Corporate Acquisitions: Post-Acqusition Strategies and Integration Capability on US Bank Mergers, Strategic Management Journal.

Matilda Andersson-Thunberg, Tobias Fjellman, Jonatan Partin. (2008). How management creates and realizes synergy cross-border mergers \& acquisitions. Thesis Jonkoping International Business School.

Michael Benaroch \& Robert J Kauffman. (2000). Justifying electronic banking network expansion using real options analysis. MIS Quarterly.

M.V. Shyam Kumar. (2006). The Value from Acquiring and Divesting A Joint Venture: A Real Options Approach. Strategic Management Journal.

PriceWaterhouseCoopers (PWC). (2008). Going for growth in Asia: Navigating the way Financial Services M\&A - Indonesia.

Ravi Chanmugam, Walt Shill, David Mann, Kristen Ficery, \& Bill Pursche. (2005). the Intelligent Clean Room: Ensuring Value Capture in Mergers and Acquisitions. The Journal of Business Strategy.

Stephen A Ross, Randolph W. Westerfield, \& Jeffrey Jaffe. (2002). Corporate Finance $\left(6^{\text {th }}\right.$ ed.). McGraw Hill

Sudarsanam, S. (2003). Creating Value from Mergers and Acquisition: The Challenges. Harlow: Pearson Education ltd.

Tom Arnold Robins. (2003). Option Pricing in the Real World: A Generalized Binomial Model with Applications to Real Options. Paper. School of Business. 
Tony W. Tong \& Jing Li. (2008). Real options and MNE strategies in Asia Pacific. Asia Pacific J Manage.

\section{Others:}

Bank Indonesia official website, www.bi.go.id.

Bloomberg LP $\underline{w w w . b l o o m b e r g . c o m}$

Indonesia Stock Exchange office website, http://www.idx.co.id/

News articles, various research reports on Indonesian banking sector including Infobank (business magazine specializing in the banking sector. 